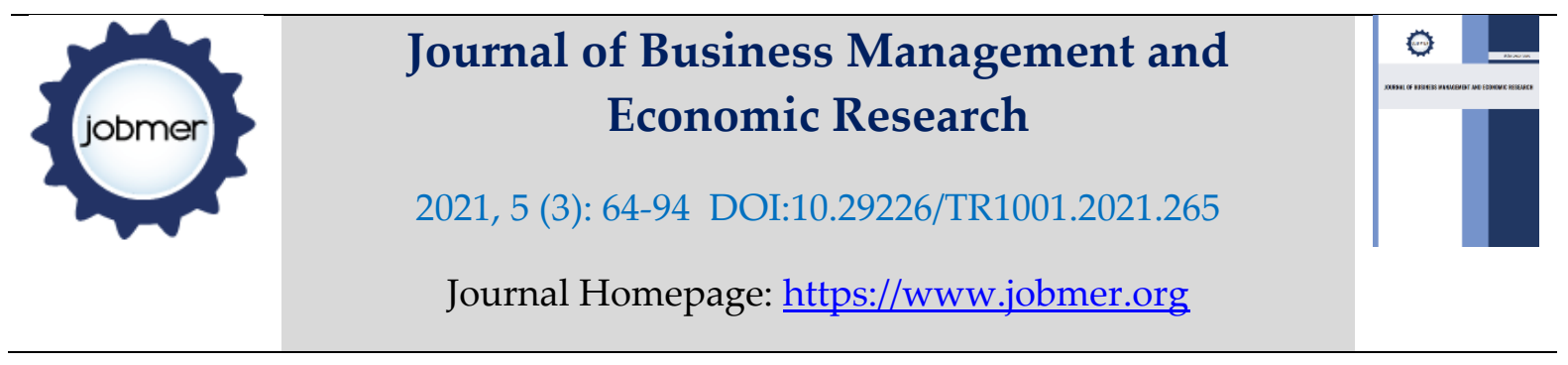

\title{
Effects of Lean Management Practices on Competitiveness of Grain Milling Firms in Uasin Gishu County-Kenya
}

\author{
George Okita \\ Master Student \\ Kisii University \\ Caleb Akuku \\ Department of Business Administration \\ Kisii University \\ Enock Musau \\ Department of Management Science \\ Kisii University \\ Robert Onyango* \\ Masinde Muliro University of Science and Technology \\ *Corresponding Author: robertonyango29@gmail.com
}

\begin{abstract}
Lean management practice has now become a critical and regular practice to achieve organizational competitiveness. Many companies such as manufacturing industry have been implementing the lean approach for many years however; there are still organizations that have a long way to go to become leaner. In this regard the grain milling industry in Kenya suffers non-competitiveness owing to problem of broad production which has remained in place as advanced technology takes its roots in Africa. Thus, the general objective of the study was to find out the effects of lean management practices on competitiveness of grain milling firms in Uasin Gishu County-Kenya. The study investigated the effects of total production maintenance practices, total flow management practices on competitiveness. This study adopted descriptive survey research design with a target population 686 employees from the four grain mailing companies in Uasin Gishu County. The sample size was 292 respondents to take care of non-response rate. Data was analyzed by use of descriptive and inferential techniques using SPSS version 25 and presented using tables. From the findings the value of adjusted $\mathrm{R}$ squared is 0.465 an indication that there was a variation of $46.5 \%$ on the competitiveness in grain milling firms in Uasin Gishu county due to total production maintenance (TPM) and total flow management (TFM) at 95\% confidence interval. Thus all the lean management practices under study have a significant effect on competitiveness as supported by both Porters generic theory and resource based view. This implies that the strategic bundling of these lean management practices remains a strategic pillar for competitiveness. There is need for the grain milling industry to strategically invest their resources to lean management practices to set them apart from their competitors.
\end{abstract}

Keywords: Lean management practices, competitiveness 
Journal of Business Management and Economic Research (JOBMER), Vol.5, Issue.3, pp.64-94

\subsection{Background to the Study}

Globally, the drive for organizational competiveness has espoused lean management from niche concept to a major theme within operations management $(\mathrm{OM})$. Lean management practices effects operational and strategic gains for the manufacturing and service organizations (Piercy \& Rich, 2015). In this regard lean management practices have advertently spanned operational and the strategic levels as a recipe of competiveness. Increase in competition has further asserted the essence of lean management amongst manufacturing companies calling for the improvement of operations, by addressing the specific needs of the business for competitiveness (Hashmi, Khan \& Haq, 2015). According to Stone (2012) lean management practices do contribute to the organizational competitiveness in terms of organizational productivity and service delivery (Stone, 2012). However, the application of lean management practices still occurred in a fragmented way, disregarding the systemic linkage that is essential to lean manufacturing (Negrão, Godinho \& Marodin, 2017).

Competitiveness defines economic strength of an entity with respect to its competitor and it has the country, industrial and enterprise perspectives (Sadegh, Senin \& Tourani, 2015). The organization is said to be competitive over its rivals, if there are dynamic, able to respond to any changes with versatility, flexibility, innovative and able to create economic value than its competitors (Houshang \& Babakhanianb, 2015). An organization inclined towards building a competitive advantage has to strategically mange all its core processes and resources. In this regard the organization must embrace the competencies to understand and operationalize the critical drivers of its processes and value addition of its resources to ameliorate their competitive position in the national and global markets. Business competitiveness depends on organizational competences (including both the static level of operational capability and the dynamic capabilities of improving and adapting to changing internal and external conditions) and business performance (Demeter, Losonci, Matyusz \& Jenei, 2009). This argumentation is premised on Michael Porters assumption that the competitiveness of a business is related to its performance in relation to other businesses (Patty, 2016). This is justified by the fact that firms compete with each other, and not countries. In this regard, enhancing competitiveness should therefore start by making the production processes of firms and industries more efficient and productive (Ewert, 2016).

Firm structure and production efficiency should be organized in such a way that firms could produce goods of the same or better quality at lower prices as this would increase sales and profits, leading to industrial growth hence competiveness (Kleynhans \& Pradeep, 2013). In this regard lean thinking has now been 
applied to a wide range of issues, spanning management, design and service delivery, and also business functions such as product development, logistics, service, sales, HR. and production (Sparrow, Hird, \& Cooper, 2015). Lean management construction is "initiative, whose objective is to decrease the leftover in human determination, inventory, time to market, and manufacturing space to become highly responsive to customer demand while producing world class quality products in the most efficient and economical manner" (Bakar, Mat, Fahmi \& Urus, 2017). To compete in the current competitive market, manufacturing firms should balance their environmental, economic and social performance. As such, manufacturering companies need to take cognizance of the lean management practices that have positive effects on all three aspects of sustainability, and not only one aspect to engender competitiveness. This is attributed to the fact that lean management practices significantly affects competitiveness of an of an organization (Bakar et al, 2017; Iranmanesh, Zailani, Hyun, Ali \& Kim, 2019; Anvari, Zulkifli, Yusuff, Hojjati \& Ismail, 2011).

Lean management is defined as a philosophy or strategy which depends on a set of practices used to reduce waste with the intention of improving the performance of enterprises (Womack \& Jones, 2013). Lean manufacturing is an integrated sociotechnical system, which comprises a package of management practices that can be applied to eliminate the waste and reduce the variability of suppliers, customers and internal resources and processes (Anvari, Zulkifli, Yusuff, Hojjati \& Ismail, 2011). Lean Management practices involves a variety of management practices that has focus on the supplier management, quality and the reducing waste. Lean Management can be considered as a synergistic set of integrated modern manufacturing management practices, commonly classified under subsets of just-in-time (JIT), total quality management (TQM), total productive maintenance (TPM), and a collection of supportive human resource management practices including teamwork and employee empowerment (Alam, 2009). Clark, Silvester and Knowles, (2013) mentioned the importance of understanding the Lean principle elimination of waste and non-value-added activities so that, Lean Management practices can be carried out perfectly.

Lean management practices subscribe to the strategies of eliminating all non-value adding aspects of the production system, for the attainment of excellent product and service. Salaheldin, (2009) agreed that in order to improve quality in organizations which directly increase organizations performance, the elimination of waste or non-value-added activity and systematic workflows are pivotal practices. Lean management practices encourage managers and change agents toward better means to "leanness" because it combines all the high variability values of selected "lean" practices (Anvari, Zulkifli, Yusuff, Hojjati \& Ismail, 2011). The business environment is highly variable thus the lean management practices need to be 
ingrained with high variability values for competitiveness. The convers would render the practices nonvalue adding with the dynamic environments. Incorrect application of lean concept leads to waste of the organizational resources and reduction in employees' confidence in practicing lean (Marvel \& Standridge, 2009). Complications of lean implementation are believed to be driven by executive, cultural, managerial, implementation and technical barriers (Flinchbaugh, 1998) cited in (Mostafa, Dumrak, \& Soltan, 2013).

Globally, competition among manufacturing and processing plants has increased pressures towards improving different factors for operational performance. According to Bicheno and Holweg (2016), it is depicted that organizations make use of broad production practice, and this is challenging because they are unable to improve and increase their production or even satisfy their customers. Kaizen has led to operational and strategic gains for the manufacturing and service organizations (Kasemsap, 2014). Recently, lean manufacturing philosophy has caught the attention of both academia and manufacturing industries around the world to meet the challenges of improving manufacturing performance and to gain a competitive advantage in the market place (Netland \& Aspelund, 2013).

Although the lean concept has been developed for automotive manufacturing industries, over time it has been established that the lean concept is transferable to a variety of other industries and organizations such as administration, construction, software \& IT, service industries, logistics, military etc. For example, in U.S. and UK some companies are embracing a business philosophy known as lean manufacturing to compete successfully in the global market (Bashir et al., 2010). Major household organizations such as Ford, General Electric, Honeywell, Honda, Delta Airlines, Toyota and General Electric have achieved a global competitiveness with lean strategies generate more revenue with fewer resources, especially since millennial employees prefer leaner, technology-linked structures, processes and practices (Shroeder, Goldstein, \& Rungtusanatham, 2011; Burch \& Smith, 2017). Dora, Kumar, Van Goubergen, Molnar and Gellynck (2013) posits that lean manufacturing practices in food SMEs is still at its infancy in European food SMEs however it improves operational performance, mainly productivity and quality. In India lean manufacturing has significantly affected the competitiveness of the food and beverage industry (Kezia \& Kumar, 2017). Taj and Morosan, (2011) indicated significant gaps in lean manufacturing practices among different industries in China, with the petroleum and hi-tech industries performing relatively best. In addition, the garment industry performs very well in flexibility, indicating it does not compete just on price, but also on rapid response. Finally, all industries perform well in quality, underlining the emerging economy character of China. 
Arguably lean management practices are a new concept with less documented implementation in developing countries and dearth of empirical research especially in Africa (Burtonshaw-Gunn, GarzaReyes, Soriano-Meier \& Kumar, 2012; Keitany \& Riwo-Abudho, 2014; Mor, Singh, \& Bhardwaj, 2016). However, a lean operation is adaptable in developing countries despite their inherent costs. In Nigeria and South African, theoretically and practically, lean manufacturing is argued to have numerous benefits in the light of waste elimination, improved and consistent quality of products and customer satisfaction (Towill, 2010). Govender and Jasson (2018) focused on South African hospitality and services sector with specific reference to lean advantages and challenges. The main findings revealed that lean management practices enhanced competitiveness of the hospitality industry. Ernest, King, Esther, Kwadwo and AY, (2019 found out in their study that lean operations had a positive effect on operational and financial performance but not marketing performance of beverage manufacturing firms in Ghana. lean manufacturing within manufacturing firms in Uganda had a positive correlation with increase in profitability levels (Mwelu, Rulangaranga, Watundu, \& Tindiwensi, 2014). Manufacturing firms in Uganda have for long been battling with poor plant performance and noncompetitive with a revealed comparative advantage (RCA) index of less than one invoking the need for a lean, agile and leagile manufacturing (Technoserve, 2008; Balikowa, 2011).

The Kenyan manufacturing industry is faced with a number of challenges one of which is competition. The manufacturing industry must compete locally with imports from well-established multinational firms while at the same time try to have a competitive edge in the world (World Bank, 2016). Studies have been conducted on the effects of lean management practices on organizational performance positing a positive relationship in the kenyan context (Keinan \& Karugu, 2018; Mohamed \& Mwanyota, 2018; Wachuma \& Shalle, 2016; Farah, 2015). However, with very limited studies on lean management practices and competitiveness of the grain milling industry in Kenya. Ondiek and Kisombe, (2012) recommended further research in the area of lean manufacturing, not only in the sugar sector but also in other areas of the Kenyan economy. Milling industries are also becoming very competitive thus forcing them to seek suitable management strategies with the intention of enhancing their competitiveness and efficiency. However, flour producing companies in Kenya, the problem of broad production has been in place and as advanced technology takes its roots in Africa (Keitany \& Riwo-Abudho, 2014). In Uasin Gishu County there is a depression of demand and increased competition adversely affecting performance of the grain milling companies (ANDAE, 2019). 
Journal of Business Management and Economic Research (JOBMER), Vol.5, Issue.3, pp.64-94

\subsection{Statement of the Problem}

The manufacturing sector has been earmarked as a crucial pillar in Kenya's development strategy as a component of the Government of Kenya's Big 4 Agenda (Kandie, 2019). In the interest of achieving this ambitious target, the manufacturing industry must compete locally with imports from well-established multinational firms while at the same time try to have a competitive edge in the world (World Bank, 2016). Grain milling industries are not an exception because they are becoming very competitive thus forcing them to seek suitable management strategies with the intention of enhancing their competitiveness and efficiency. In order to remain competitive, many organizations are now improving the quality of their products, decreasing cost and meeting the unexpected need of their customers through lean management practices (Bicheno, 2016). According to Stone (2012) lean management practices do contribute to the organizational competitiveness in terms of organizational productivity and service delivery (Stone, 2012).

Lean management practices leverage companies to achieve long term competitive advantages (Womack \& Jones, 2013). However, the competitiveness of Kenya manufacturing sector has been slowly declining from 0.18\% in 1980 down to $0.06 \%$ in 1994 and 0.02\% in 2013 (World Bank., 2014). Grain milling industry in Kenya suffers non-competitiveness owing to problem of broad production has been in place and as advanced technology takes its roots in Africa (Keitany \& Riwo-Abudho, 2014). In Uasin Gishu County there is a depression of demand and increased competition adversely affecting performance of the grain milling companies (ANDAE, 2019). This calls for the adoption of lean management practices which is linked to efficiency production, in which increasing profits come from reducing costs, contrasts with the focus on margin, in which costs are unquestionable and added up to a desired profit level (Shingo, 2016).

Studies have been conducted on the effects of lean management practices on organizational performance positing a positive relationship in the Kenyan context (Keinan \& Karugu, 2018; Mohamed \& Mwanyota, 2018; Wachuma \& Shalle, 2016; Farah, 2015). However, with very limited studies on lean management practices and competitiveness of the grain milling industry in Kenya. Ondiek and Kisombe, (2012) recommended further research in the area of lean manufacturing, not only in the sugar sector but also in other areas of the Kenyan economy. This has motivated the design of the current study to fill in the gap in the literature with limited conceptual and empirical knowledge on the effect of lean management practices on competitiveness of the grain milling firms in Uasin Gishu County-Kenya. 
Journal of Business Management and Economic Research (JOBMER), Vol.5, Issue.3, pp.64-94

\subsection{Objective of the Study}

\subsubsection{General Objective}

The general objective of this study will be to investigate the effect of lean management practices on competitiveness of grain milling firms in Uasin Gishu County.

\subsubsection{Specific Objective}

The following specific objectives will guide the study;

- To establish the effects of total production maintenance practices on competitiveness of grain milling firms in Uasin Gishu County.

- To find out the effects of total flow management practices on competitiveness of grain milling firms in Uasin Gishu County.

\section{Literature Review}

\subsection{Empirical Review}

The empirical review will cover the effect of the lean management practices as the independent variable which includes, total production maintenance practices, total flow management practices and how they affect competitiveness.

\subsubsection{Total production maintenance practices and competitiveness}

Total productive maintenance (TPM) is a process of maintenance management that empowers the organization with a progressive, continuous philosophy of enabling all manpower resources to work together to accomplish the mutual goal of manufacturing efficiency (Digalwar \& Nayagam, 2014). Total productive maintenance (TPM) is one of the best tools for making our industries competitive and effective in the field of maintenance (Hanged \& Kumar, 2013). The rapidly changing market requirements call for improvements in a company's performance by focusing on cost cutting, increasing productivity levels and quality and timely delivery to satisfy customers. The quality and maintenance functions are vital factors for achieving sustainability in a manufacturing organization (Kaur, Singh \& Ahuja, 2013). TPM drives productivity and efficiency of employees and equipment besides registration of a positive inclination towards the company. In this regard equipment maintenance remains an indispensable function in a manufacturing enterprise. Thus, there is need to evaluate the interrelationships between various TQM \& TPM organizational initiatives with the business performance improvement parameters to efficiently 
Journal of Business Management and Economic Research (JOBMER), Vol.5, Issue.3, pp.64-94

manage the synergic TQM \& TPM paradigms to realize organisational objectives of growth and sustainability (Kaur, Singh \& Ahuja, 2013). TPM recognizes and attempts to realize the needs of people such as self-esteem, morale, safety and job satisfaction (Kulkarni \& Dabade, 2013). The principal features of TPM are the economic efficiency or profitability, maintenance prevention, improving maintainability, the use of preventive maintenance and total participation of all employees (Habidin, Hashim, Fuzi \& Salleh, 2018)

TPM is a strategic change management approach that has a considerable impact on the internal efficiency of manufacturing organization by increasing the effectiveness of the production environment, especially through increasing the effectiveness of equipments (Sharma, Gera, Kumar, Chaudhary, \& Gupta, 2012). TPM uses Pareto analysis, statistical process control (control charts, etc.), problem-solving techniques (brainstorming, cause- effect diagrams and 5-M approach), team-based problem solving, poka-yoke systems, autonomous maintenance, continuous improvement, 5S, setup time reduction, waste minimization, bottleneck analysis, recognition and reward program and simulation as tools to analyze and solve problems (Jain, Bhatti \& Singh, 2014). TPM implementation is not short-term planning; it takes time to change the attitude of top management as well as employees (Panneerselvam, 2012). Its implementation can significantly contribute towards improvement in organizational behavior in the manufacturing enterprises leading to world class competitiveness (Gupta \& Garg, 2012; Haddad \& Jaaron, 2012;Badli Shah, 2012;Kaur, Singh \& Ahuja, 2013). TPM is useful but should be treated with caution owing to its inherent strength and weakness and also in some cases a certain amount of overlap with other practices (Kedar, Deshpande, Washimkar \& Wakhare, 2008).

Habidin, Hashim, Fuzi and Salleh, (2018) determined the relationship between total productive maintenance (TPM), kaizen event (KE) and innovation performance (IP) for Malaysian automotive industry using structural equation modeling (SEM). The samples were selected from the list of Proton and Perodua automotive industry. The number of collected respondents was 238 respondents. An SEM technique was used in the study. In order to test the reliability and validity of the instrument, reliability analysis, exploratory and confirmatory factor analysis were conducted. Based on the results, KE does not affect the relationship between TPM and IP. However, the impact of TPM on IP increases with mediating of KE for Malaysian automotive industry. However, this study only focused on the Malaysian automotive industry. The other limitation in this research is the number of factors and limited measurement in this study. Only 
a few TPM, KE and IP measurements were considered. By using the SEM technique, four TPM constructs, three for KE constructs and three for IP measures were developed and verified.

Nzewi and Chiekezie (2016) did a study on total productivity maintenance and performance of selected aluminum manufacturing companies in Anambra State. The study employed a correlation research design. It was anchored on the Theory of Structural Empowerment. Pearson's Product Moment Correlation Coefficient was used in analyzing the data. The findings revealed that Maintenance Autonomy has a significant positive relationship with Employee Commitment. However, the study advocated that management should empower the operatives by giving them necessary working resources to succeed in the maintenance activity. Effort should be geared towards avoiding stock out syndrome. In addition, state of the art equipment should be provided in order to ensure optimum level of coordination among the various departments in the organizations.

Wakjira and Singh (2012) studied total productive maintenance: A case study in manufacturing industry. The study focused upon the significant contributions of TPM implementation success factors like top management leadership and involvement, traditional maintenance practices and holistic TPM implementation initiatives, towards affecting improvements in manufacturing performance in the Ethiopian industry. The study established that focused TPM implementation over a reasonable time period can strategically contribute towards realization of significant manufacturing performance enhancements. The study highlighted the strong potential of TPM implementation initiatives in affecting organizational performance improvements. The achievements of Ethiopian manufacturing organizations through proactive TPM initiatives have been evaluated and critical TPM success factors identified for enhancing the effectiveness of TPM implementation programs in the Ethiopian context.

Keny, (2015) investigated how Total Productive Maintenance (TPM) has affected the performance of the Kenya seed industry. This study was justified by plant maintenance revolution that has been fueled by competition and growth which has led industries to leverage on TPM to outpace the competition. The survey was cross sectional in nature since it covered a sample of 47 companies in various segments of the Kenya seed industry. The research employed stratified sampling technique in which the seed companies were stratified into four stratums according to their functions. The study used both primary and secondary data. Primary data was collected using structured questionnaires. The data and information obtained through the questionnaires was first checked for completeness and consistency and then analyzed based on descriptive statistics. Findings indicate that $52.6 \%$ of firms sampled have implemented TPM practices. 
The study also showed that planned maintenance and quality maintenance were the most implemented TPM pillars while development management and office TPM were the least implemented. Management leadership and commitment, employee empowerment and involvement, continuous improvement, adoption of new technology and organizational culture change were found to be critical factors that will ensure the success of TPM in an organization. Finally, the study showed that implementation of TPM practices in an organization not only improve the operating performance but also the profitability. However, the study was not conducted in the manufacturing setting and also didn't focus on competitiveness thus providing the gap for the current study.

Ngugi, (2015) explored the relationship between the implementation of total productive maintenance (TPM) practices and the equipment effectiveness of a typical large scale manufacturing concern in Kenya, taking the case of Bamburi Cement Limited (BCL). The study used secondary data collected from the organisation's archived records. Inferential statistics was used to analyse and present the data. The preliminary results of the analysis showed that the implementation of TPM practices at BCL caused a significant increase in the equipment effectiveness in the organization. The analysis also showed that of the many TPM practices deployed, autonomous maintenance of equipment by production operators played the biggest role in increasing the equipment effectiveness. However, the study appreciated the role of TPM on equipment effectiveness but not competitiveness besides the study was not conducted in the grain miling industry providing the gap for the current study.

\subsubsection{Total flow management practices and competitiveness}

Total Flow Management is a management re-organisation system that influences all the work processes of a company, involving all corporate activities: sales \& operation planning, purchases, stores logistics, production, quality and distribution (Molina., 2019). The essential objective of the method is to reduce waste and optimize processes so that the company works in a more streamlined, effective and efficient way to reduce time to market. According to Sony (2019) TFM is then defined as an integrated concept to increase Process Flow and Effectiveness (Pull) across the Totality of a Supply Chain. Reducing lead time also eliminates muda of waiting and really means creating a material flow. The systems, processes and standards necessary to create and maintain this flow, require a high level of rigor and bring about very important results in terms of: cost reduction; increased productivity; increased quality; increased customer service and satisfaction (Chiocca, Guizzi, Murino, Revetria, \& Romano, 2012). 
The goal of total flow management practices is to fill the production capacity, give stability to the entire supply chain, reduce inefficiencies and increase product and service level (Molina., 2019). Total flow management has been the cornerstone of effective supply chain management (SCM) which has equally become a potentially valuable way of securing competitive advantage and improving organizational performance. Thus, it becomes quintessential for organizations to ensure that they explore ways of ensuring that they optimize on their total flow management. Material management and physical distribution are positively related and are therefore critical determinants of successful lean production practice within the organization as a precursor of organizational competitiveness (Riwo-Abudho \& Keitany, 2014).

Agu (2016) ascertained the extent at which inventory control affect the productivity of selected manufacturing firms, to determine the nature of the relationship between demand management and customer satisfaction of selected manufacturing firms and to determine the effect of Just - in- time on the growth of selected manufacturing firms in Nigeria. The study had a population size of 996, out of which a sample size of 285 was realized using Taro Yemeni's formula at 5\% error tolerance and $95 \%$ level of confidence. The instrument used for data collection was primarily questionnaire and interview. Out of 285 copies of the questionnaire that were distributed, 270 copies were returned while 15 were not returned. The descriptive survey research design was adopted for the study. The hypotheses were tested using Pearson product moment correlation coefficient and simple linear regression statistical tools. The findings indicate that inventory control significantly affects productivity of selected manufacturing firms. There is a positive relationship between demand management and customer satisfaction of selected manufacturing firms. Just - in - time has a significant effect on growth of the selected manufacturing firms. The study concluded that inventory management is essential in the operation of any business. Inventory as an asset on the balance sheet of companies has taken on increased importance because many companies are applying the strategy of reducing their investment in fixed assets. However, the study didn't focus on performance as an outcome and not competitiveness. Besides it focused only on one practice of total flow management practices.

Coleman Sr, (2014) Applying the Total Flow Management in the first instance organization want to create an internal pull flow in maximum operational efficiency and free of non-value added (NVA), then consider the extension to the valley (the delivery side such as customers) and upstream (the source side, such as the suppliers). The flow of materials can be considered as a repeated sequence of four types of transaction, 
namely transport, inspection, waiting and transformation, the only real value-added activities (Mana \& César, 2017). The main objective is the reduction of total lead time, as measured coverage of stocks, eliminating muda process, creating benefits in terms of cost reduction and working capital, increased productivity and quality in order to achieve a higher level of service provided to customers and to improve, therefore, the satisfaction. Organization can reach these objectives through the redesign of logistics and implementation of the one-piece flow loop, driven by actual customer orders, which define the so-called customer takt, quantifying the need for restocking of inventories and production volumes. Therefore, orders the production or distribution are no longer based on predictive models, which are still useful for capacity management (Guizzi, Chiocca \& Romano, 2012). According to Sander, Matthias and Geoff (2010) historically, however, organizations have ignored the potential savings from proper inventory management, treating inventory as a necessary evil and not as an asset requiring management.

Musau, Namusonge, Makokha and Ngeno (2017) analyzed the effect of inventory management on supply chain performance in terms of profitability, reliability, cost, responsiveness, flexibility and asset management efficiency of textile manufacturing firms in Kenya. The study adopted the convergent parallel mixed methods design. The study targeted a total of 196 respondents drawn from employees of procurement departments and departmental heads of respective 15 textile manufacturing industries operating in Nairobi County. The sample size was therefore 139 respondents. Stratified and simple random sampling methods were used to select employees of procurement departments from their respective textile firms. Questionnaires and interview schedules were used to gather the data from primary sources. The study applied the use of both qualitative and quantitative data which was analyzed using statistical package for social sciences (SPSS Version 22). Inferential statistics using hierarchical multiple regression and Correlation analysis was applied to test the relationship between the variable and formulated hypothesis. The study established that textile manufacturing firms in Kenya have adoption of inventory management as a factor of supply chain influencing performance. However, the study focused on the textile industry thus findings may not be generalized to the grain milling industry. Besides the study focused on an aspect of total flow management and how it affects performance and not competitiveness thus providing a gap for the current study.

Mwaura, Letting, Ithinji and Orwa (2015) Reverse Logistics Practices and Their Effect on Competitiveness of Food Manufacturing Firms in Kenya. A cross- sectional survey was conducted among 130 food manufacturing firms that are listed in the Kenya Association of Manufacturers directory. The response rate 
was $73.8 \%$. Primary data was collected through questionnaires. Factor analysis was used examine the construct validity while multivariate liner regression was employed to test criterion validity. The results of this research indicated that, the adoption of reverse logistics practices would enhance the competitiveness of Kenya's food manufacturing firms. Further this study found that due to lack of awareness on the importance of sustainability, there is a low level of adoption of reverse logistics practices in Kenya. The study focused on reverse logistics and its effects on competitiveness an aspect of total flow management leaving other aspects sales \& operation planning, purchases, stores logistics, production, quality and distribution.

\subsection{Conceptual Framework}

Conceptual framework is a presentation of how the independent and dependent variables are related. The relationship between variables is such that the independent variables stand-alone factor(s) which jointly affects the existence of a scenario under investigation - Cooper and Schidler (2000). The study adopts a conceptual frame whereby it shows the relationship between lean management practices and competitiveness in grain milling companies. The researcher looks at the lean management practices which are an independent variable which includes the following; quality, flexibility, leads time reduction and cost reduction. The dependent variables consist of competitiveness (quick response to the market, increased market share, customer trust and increased supplier networks) in grain milling companies. This can be best illustrated diagrammatically below.

Independent Variables (X)

\begin{tabular}{|c|c|}
\hline $\begin{array}{l}\text { Total production maintenance practices } \\
\text { - Autonomous maintenance }\end{array}$ & \\
\hline $\begin{array}{ll}\text { - } & \text { Condition based maintenance } \\
\text { - } & \text { Kobetzu Kaizen (Focused improvement) } \\
\text { - } & \text { Planned maintenance } \\
\text { - } & \text { Monitoring of MTR, MTBF and OEE }\end{array}$ & $\begin{array}{l}\text { Competitiveness in grain milling } \\
\text { companies }\end{array}$ \\
\hline $\begin{array}{l}\text { Total flow management practices } \\
\text { - } \quad \text { Value stream mapping } \\
\text { - } \quad \text { Process mapping } \\
\text { - } \quad \text { Layout and design }\end{array}$ & $\begin{array}{ll}\text { - } & \text { Flexibility } \\
\text { - } & \text { Lead time reduction } \\
\text { - } & \text { Cost reduction }\end{array}$ \\
\hline
\end{tabular}

(Source: Researcher, 2020)

Figure 1. Conceptual Framework 
Journal of Business Management and Economic Research (JOBMER), Vol.5, Issue.3, pp.64-94

\section{Research Methodology}

\subsection{Research Design}

The research design is the blueprint for collecting, measuring, and analyzing data (Klassen, Creswell, Clark, Smith \& Meissner, 2012). This study adopted a descriptive survey as the primary research design. The choice of this design is was dictated by its effectiveness to secure evidence concerning all existing situations or current conditions, to identify standards or norms with which to compare present conditions in order to determine how to take the next step, having determined where one is and where they wish to go (Curtis, Murphy\& Shields, 2013). Therefore, using this design, the researcher aimed at collecting information on the effects of lean management practices on competitiveness in grain milling in Uasin Gishu County-Kenya.

\subsection{Target Population}

The target population was the management of grain milling companies. Study population (also known as accessible population) is the actual sampling frame, from which we randomly drew our sample. The accessible or study population is the portion of the population to which the researcher has reasonable access; may be a subset of the target population (Stan, 2020). The accessible population was 686 respondents who included the top and middle level management and lower level employees of four grain milling firms in Uasin Gishu County-Kenya. They include; Jamii Milling Ltd, Eldoret Grains Ltd, Mfalme grain milling company and Unga Limited - Eldoret.

Table 1. Accessible Population

\begin{tabular}{llc}
\hline Milling Companies & Strata & Population \\
\hline Unga Limited & Top Management & 5 \\
& Middle & 8 \\
& Shop Floor & 272 \\
Eldoret Grain Millers (Dola) & Top Management & 4 \\
& Middle & 8 \\
& Shop Floor & 173 \\
Bufallo Millers (Mfalmers) & Top Management & 4 \\
& Middle & 5 \\
Jamii Millers & Shop Floor & 115 \\
& Top Management & 4 \\
Total & Middle & 5 \\
& Shop Floor & 83 \\
& & $\mathbf{6 8 6}$ \\
\hline
\end{tabular}




\subsection{Sample Size and Sampling Procedure}

The sample size for this study was calculated from the target population, due to their small number and ease of location. According to Berinsky (2008) a good sample size is a necessity, and a large sample size is almost always better than a small sample size. Sample size was determined by a sampling formula proposed by Krejcie and Morgan (1970), from the table, the sample corresponding to a population of 686 is 248 respondents that was selected for this study. The distribution of the sample size within the grain milling companies was done through proportional allocation technique as shown in table 2.

The formula for Neyman Allocation is following:

Where,

$$
n_{h}=\left(\frac{N_{h}}{N}\right) n
$$

$n_{h}$ - The sample size for strata $h$,

n - Total sample size,

$\mathrm{N}_{\mathrm{h}}$-The population size for strata $\mathrm{h}$,

$\mathrm{N}$ - The total population

Table 2. Sample Size

\begin{tabular}{llcc}
\hline Milling Companies & Strata & Population & Sample Size \\
\hline Unga Limited & Top Management & 5 & 2 \\
& Middle & 8 & 3 \\
& Shop Floor & 272 & 98 \\
Eldoret Grain Millers (Dola) & Top Management & 4 & 1 \\
& Middle & 8 & 3 \\
& Shop Floor & 173 & 63 \\
Bufallo Millers (Mfalmers) & Top Management & 4 & 1 \\
& Middle & 5 & 2 \\
Jamii Millers & Shop Floor & 115 & 42 \\
& Top Management & 4 & 1 \\
& Middle & 5 & 2 \\
Total & Shop Floor & 83 & 30 \\
\hline
\end{tabular}

The nonresponse rate is defined as the percentage of all potentially eligible units (or elements) that do not have responses to at least a certain proportion of the items in a survey questionnaire. According to this a study in which all data from a sampled respondent are missing will be considered using the following formula adopted from (Nilima, 2017). 
Final sample size= Effective sample size/ (1- non response rate anticipated) (Suresh \& Chandrashekara, 2012). If the study anticipates a non-response rate of $15 \%$. Therefore, the final sample size will be $248 / 1$ $0.15=291.8$. Therefore, the final sample size will be 292 respondents.

\subsection{Data Collection Instrument}

Data collection method is the systematic gathering of information from a sample population so as to accurately answer a question in a given area of interest (Ghauri, Gronhaug \& Strange, 2020). The study used primary data collection instruments. Primary data entails collection of information for the first time and it was done through the use of closed ended questionnaires which was self-administered. Likert scale was anchored on a five-point rating ranging from strongly disagreeing to strongly agree used in the design of the questionnaires (1 depicted Strongly Disagree, 2-Disagree, 3-Moderately Agree, 4-Agree and 5Strongly Agree).

\subsection{Data Analysis}

The raw data was collected from the questionnaires which were systematically organized in a manner as to facilitate analysis. Where quantitative data was collected, numbers were assigned for the possible responses, for example where the response is Strongly agree, Agree Undecided, Disagree and Strongly disagree numbers 5, 4, 3, 2, and 1 was assigned for the responses respectively. The data was entered into the Statistical package for social scientists (SPPS) version 25 and analyzed. Data was analyzed by both descriptive and inferential statistics. The study employed multiple regression model in data analysis. The following model was used to show the relationship between LM practices and the competitiveness:

$\mathrm{Y}=\mathrm{a}+\mathrm{B} 1 \mathrm{X} 1+\mathrm{B} 2 \mathrm{X} 2+\varepsilon$ .Eqn 3.1

Where $\mathrm{Y}=$ competitiveness, $\mathrm{a}=$ the $\mathrm{Y}$ intercept when $\mathrm{x}=\mathrm{B} 1$, and $\mathrm{B} 2$, are the regression weights attached to the variables;

$\mathrm{X} 1=$ total production maintenance practices,

$\mathrm{X} 2=$ total flow management practices,

$\varepsilon=$ the error term (To account for all other Variables not considered in the study), assumed to be normally distributed with mean zero and constant variance. 
Journal of Business Management and Economic Research (JOBMER), Vol.5, Issue.3, pp.64-94

\section{Data Analysis, Results Findings and Discussion}

\subsection{Descriptive Results for Variables}

The study sought to establish the descriptive results for the lean management practices as total quality management practices, total production maintenance practices, total flow management practices and safety health, environment practices as independent variables and competitiveness as the dependent variables as represented.

\subsubsection{Descriptive Statistics of Total Production Maintenance Practices}

Total productive maintenance (TPM) is one of the best tools for making our industries competitive and effective in the field of maintenance (Hanged \& Kumar, 2013). Thus, the study sought to establish the state of Total productive maintenance (TPM) in the grain milling companies. According to table 3 a total of $70.3 \%$ of the respondents both agreed and strongly agreed that their company encourages operators to do maintenance in favor of the company $(\mathrm{M}=3.90 \mathrm{SD}=1.045), 13.1 \%$ were in disagreement while $16.6 \%$ were undecided. Besides, a majority of the employees $66.9 \%$ of the respondents agree that their company develop and implement condition-based maintenance checklist and schedule ( $\mathrm{M}=3.85 \mathrm{SD}=1.322), 22.6 \%$ were in disagreement while undecided were $10.6 \%$. A total of $67.8 \%$ of the respondents also agreed and strongly agreed that their company encourages employees to work together to improve and achieve maximum

productivity ( $M=4.11 \mathrm{SD}=.988), 7.5 \%$ disagreed and strongly disagreed while $24.6 \%$ were undecided. A total of $68.3 \%$ of respondents agreed and strongly agreed that their company emphasizes proactive and preventative maintenance to maximize the operational inefficiency of equipment ( $\mathrm{M}=3.96 \mathrm{SD}=1.050), 6.0 \%$ strongly disagreed and disagreed while $25.6 \%$ were undecided. Lastly $77.9 \%$ of the respondents agreed and strongly agreed that their company encourages continuous monitoring of equipment performance $(\mathrm{M}=4.07 \mathrm{SD}=.856), 5.5 \%$ were in disagreement while $16.6 \%$ were undecided. The milling companies practice total productive maintenance for competitiveness. The implication of this is that there should be policy frameworks which recognize and enhance total productive maintenance within various domains of their operations. 
Journal of Business Management and Economic Research (JOBMER), Vol.5, Issue.3, pp.64-94

Table 3. Descriptive Statistics of Total Production Maintenance Practices

\begin{tabular}{|c|c|c|c|c|c|c|c|}
\hline Responses & SD \% & $\mathrm{D} \%$ & UD\% & $\mathrm{A} \%$ & SA $\%$ & MEAN & SD \\
\hline $\begin{array}{l}\text { My company encourages } \\
\text { operators to do } \\
\text { maintenance in favor of the } \\
\text { company }\end{array}$ & 2.0 & 11.1 & 16.6 & 43.2 & 27.1 & 3.82 & 1.017 \\
\hline $\begin{array}{l}\text { My company develop and } \\
\text { implement condition based } \\
\text { maintenance checklist and } \\
\text { schedule }\end{array}$ & 3.5 & 19.1 & 10.6 & 16.6 & 50.3 & 3.91 & 1.300 \\
\hline $\begin{array}{l}\text { My company encourages } \\
\text { employees to work } \\
\text { together to improve and } \\
\text { achieve maximum } \\
\text { productivity }\end{array}$ & 0.0 & 7.5 & 24.6 & 20.6 & 47.2 & 4.08 & 1.010 \\
\hline $\begin{array}{l}\text { My company emphasizes } \\
\text { proactive and preventative } \\
\text { maintenance to maximize } \\
\text { the operational } \\
\text { inefficiency of equipment }\end{array}$ & 2.5 & 3.5 & 25.6 & 29.1 & 39.2 & 3.99 & 1.010 \\
\hline $\begin{array}{l}\text { My company encourages } \\
\text { continuous monitoring of } \\
\text { equipment performance }\end{array}$ & 0.0 & 5.5 & 16.6 & 44.2 & 33.7 & 4.06 & .851 \\
\hline $\begin{array}{l}\text { Total Production } \\
\text { Maintenance Practices }\end{array}$ & & & & & & 4.01 & .651 \\
\hline
\end{tabular}

Source: Research Data, (2021)

\subsubsection{Descriptive Statistics of Total Flow Management Practices}

The goal of total flow management practices is to fill the production capacity, give stability to the entire supply chain, reduce inefficiencies and increase product and service level (Molina., 2019). Results presented in Table 4 reveal that a total of $58.3 \%$ of respondents both agree and strongly agree that their company is sensitive to quick response to customers' involvement and demand for customized products ( $\mathrm{M}=3.61$ $\mathrm{SD}=1.298), 28.6 \%$ strongly disagreed and disagreed while $13.1 \%$ were undecided. Besides, a $59.3 \%$ of the employees both agreed and strongly agreed that their company periodically carry out process mapping with an aim of eliminating non-value adding activities (M=3.75 SD=1.183) while 19.1\% disagreed and strongly disagreed while $21.6 \%$ were undecided. $58.8 \%$ of respondents agreed and strongly agreed that their company periodically review layout design to enhance operational efficiency $(\mathrm{M}=3.78 \mathrm{SD}=1.173)$, $19.6 \%$ disagreed $21.6 \%$ were undecided. $55.3 \%$ agreed and strongly agreed that their company monitor JIT 
parameter such as cycle time, throughput time and takt time, $(\mathrm{M}=3.79 \mathrm{SD}=1.182), 15.6 \%$ strongly disagreed and disagreed. $29.1 \%$ were undecided. Lastly $66.3 \%$ of the respondents tend to agree that their company continuously improve single minute exchange of die to eliminate changeover downtime and delays ( $\mathrm{M}=3.98 \mathrm{SD}=1.144)$ while $16.1 \%$ strongly disagreed and disagreed $17.6 \%$ were undecided.

Table 4. Descriptive Statistics of Total Flow Management Practices

\begin{tabular}{|c|c|c|c|c|c|c|c|}
\hline Responses & SD \% & $\mathrm{D} \%$ & UD\% & $\mathrm{A} \%$ & SA \% & MEAN & SD \\
\hline $\begin{array}{l}\text { My company is sensitive } \\
\text { to quick response to } \\
\text { customers' involvement } \\
\text { and demand for } \\
\text { customized products }\end{array}$ & 4.0 & 24.6 & 13.1 & 23.1 & 35.2 & 3.61 & 1.298 \\
\hline $\begin{array}{l}\text { My company periodically } \\
\text { carry out process } \\
\text { mapping with an aim of } \\
\text { eliminating non value } \\
\text { adding activities }\end{array}$ & 2.0 & 17.1 & 21.6 & 22.1 & 37.2 & 3.75 & 1.183 \\
\hline $\begin{array}{l}\text { My company periodically } \\
\text { review layout design to } \\
\text { enhance operational } \\
\text { efficiency }\end{array}$ & 0.5 & 19.1 & 21.6 & 19.6 & 39.2 & 3.78 & 1.173 \\
\hline $\begin{array}{l}\text { My company monitor JIT } \\
\text { parameter such as cycle } \\
\text { time, throughput time } \\
\text { and takt time }\end{array}$ & 2.0 & 13.6 & 29.1 & 13.6 & 41.7 & 3.79 & 1.182 \\
\hline $\begin{array}{l}\text { My company } \\
\text { continuously improve } \\
\text { single minute exchange } \\
\text { of die to eliminate } \\
\text { changeover downtime } \\
\text { and delays }\end{array}$ & 0.0 & 16.1 & 17.6 & 18.1 & 48.2 & 3.98 & 1.144 \\
\hline $\begin{array}{l}\text { Total Flow Management } \\
\text { Practices }\end{array}$ & & & & & & 3.82 & .744 \\
\hline
\end{tabular}

Source: Research Data, (2021)

\subsubsection{Descriptive Statistics of Competitiveness}

The dependent variable of the study was competitiveness of grain milling firms in Uasin Gishu county. Results presented in Table 5, reveals that $89.9 \%$ of respondents concurred that their company provides quality products to the customers' needs $(\mathrm{M}=4.33 \mathrm{SD}=.666)$ while $0.5 \%$ were in disagreement. $91.4 \%$ of the respondents were of the view that the company is flexible in terms of schedule, product change, and 
Journal of Business Management and Economic Research (JOBMER), Vol.5, Issue.3, pp.64-94

product release $(\mathrm{M}=4.41 \mathrm{SD}=.651), 1.0 \%$ were in disagreement while $6.5 \%$ were undecided. $83 \%$ of the respondents were also in agreement that their company responds faster to the market as a result of reduced lead time $(\mathrm{M}=4.35 \mathrm{SD}=.770), 0.5 \%$ were in a disagreement while $16.6 \%$ were undecided. $79.4 \%$ of the respondents agreed that their company practices cost reduction as a way of gaining market share $(\mathrm{M}=4.23$ $\mathrm{SD}=.770$ ) while $20.6 \%$ were undecided. $80.4 \%$ of the respondents also agreed that their company products demand are on the rise $(\mathrm{M}=4.29 \mathrm{SD}=.788)$ while $0.5 \%$ were in disagreement and $19.1 \%$ were undecided.

Table 5. Descriptive Statistics of Competitiveness

\begin{tabular}{|c|c|c|c|c|c|c|c|}
\hline Responses & SD \% & $\mathrm{D} \%$ & UD\% & $\mathrm{A} \%$ & SA\% & MEAN & SD \\
\hline $\begin{array}{l}\text { My company provides quality } \\
\text { products to the customers' needs }\end{array}$ & 0.0 & 0.5 & 9.5 & 46.7 & 43.2 & 4.33 & .666 \\
\hline $\begin{array}{l}\text { My company is flexible in terms of } \\
\text { schedule, product change, and } \\
\text { product release }\end{array}$ & 0.0 & 1.0 & 6.5 & 43.2 & 49.2 & 4.41 & .659 \\
\hline $\begin{array}{l}\text { My company responds faster to the } \\
\text { market as a result of reduced lead } \\
\text { time }\end{array}$ & 0.0 & 0.5 & 16.6 & 30.2 & 52.8 & 4.35 & .770 \\
\hline $\begin{array}{l}\text { My company practices cost } \\
\text { reduction as a way of gaining } \\
\text { market share }\end{array}$ & 0.0 & 0.0 & 20.6 & 35.7 & 43.7 & 4.23 & .770 \\
\hline $\begin{array}{l}\text { My company products demand are } \\
\text { on the rise }\end{array}$ & 0.0 & 0.5 & 19.1 & 31.2 & 49.2 & 4.29 & .788 \\
\hline Competitiveness & & & & & & 4.36 & 0.568 \\
\hline
\end{tabular}

Source: Research Data, (2021)

\subsection{Regression Analysis}

The study used multiple regression analysis so as to establish the relationship of independent variables and dependent variable that is lean management practices and competitiveness of grain milling firms in Uasin Gishu County.

\subsubsection{Effect of total production maintenance practices on competitiveness of grain milling firms} in Usain Gishu County

Objective one of the study sought to establish the effects of total production maintenance practices (TPM) on competitiveness of grain milling firms in Uasin Gishu County. From the findings in table 4.17 the value of adjusted $\mathrm{R}$ squared is 0.176 an indication that there is a variation of $17.6 \%$ on competitiveness of grain milling firms due to total production maintenance practices at $95 \%$ confidence interval. This shows that 
$17.6 \%$ changes in competitiveness of grain milling firms could be accounted to changes in total production maintenance practices while other factors not considered in this study account for only $82.4 \%$ of the changes in competitiveness of grain milling firms. $\mathrm{R}$ is the correlation coefficient which shows the relationship between the study variables. From the findings shown in the table 6 below there was a fairly strong positive relationship between the study variables as shown by 0.425 .

Table 6. Model Summary

\begin{tabular}{llcccc} 
Model & $\mathrm{R}$ & R Square & $\begin{array}{c}\text { Adjusted } \mathrm{R} \\
\text { Square }\end{array}$ & $\begin{array}{c}\text { Std. Error of the } \\
\text { Estimate }\end{array}$ & Durbin-Watson \\
\hline 1 & $.425^{\mathrm{a}}$ & .180 & .176 & .453 & 1.400 \\
\hline
\end{tabular}

a. Predictors: (Constant), TPM

b. Dependent Variable: Competitiveness

The statistical significance of this value was reported in the ANOVA table where the analysis results revealed that the significance of F statistics (43.342) is 0.000 which is less than 0.05 . This implies that there is a significant relationship between total production maintenance practices and competitiveness as seen in table 7. This tested the null hypothesis and indicated that total production maintenance practices significantly affects competitiveness in grain milling firms in Uasin Gishu county. Thus, the rejection of the null hypothesis. These findings were supported by Habidin, Hashim, Fuzi and Salleh, (2018) and Jain, Bhatti and Singh (2014).

Table 7. ANOVA ${ }^{a}$

\begin{tabular}{|c|c|c|c|c|c|c|}
\hline Model & & Sum of Squares & $\mathrm{df}$ & Mean Square & $\mathrm{F}$ & Sig. \\
\hline \multirow[t]{3}{*}{1} & Regression & 8.912 & 1 & 8.912 & 43.342 & $.000^{\mathrm{b}}$ \\
\hline & Residual & 40.506 & 197 & .206 & & \\
\hline & Total & 49.417 & 198 & & & \\
\hline
\end{tabular}

a. Dependent Variable: Competitiveness

b. Predictors: (Constant), TPM

The regression coefficients table 8 showed the contribution of the independent variable to the dependent variable. Finally, from the data in Table 8, the study established regression equation was $\mathrm{Y}=3.015+.326 \mathrm{X} 1$. Therefore, competitiveness in grain milling firms in Uasin Gishu county $=3.015+.326$ TPM. 
From the above regression equation it was revealed that holding TPM to a constant zero, competitiveness in grain milling firms in Uasin Gishu county would be be at 3.015 units. A unit increase in TPM would lead to increase in competitiveness in grain milling firms in Uasin Gishu county by a factor of 0.326 ( $B=0.326$, $\mathrm{P}<0.05)$.

Table 8. Regression Coefficients ${ }^{a}$

\begin{tabular}{|c|c|c|c|c|c|c|c|}
\hline \multirow[b]{2}{*}{ Model } & \multicolumn{2}{|c|}{$\begin{array}{l}\text { Unstandardized } \\
\text { Coefficients }\end{array}$} & \multirow{2}{*}{$\begin{array}{c}\text { Standardized } \\
\text { Coefficients } \\
\text { Beta }\end{array}$} & \multirow[b]{2}{*}{$\mathrm{t}$} & \multirow[b]{2}{*}{ Sig. } & \multicolumn{2}{|c|}{ Model } \\
\hline & B & Std. Error & & & & Tolerance & VIF \\
\hline 1 (Constant) & 3.015 & .201 & & 15.001 & .000 & & \\
\hline TPM & .326 & .049 & .425 & 6.583 & .000 & 1.000 & 1.000 \\
\hline
\end{tabular}

a. Dependent Variable: Competitiveness

4.2.2. Effect of total flow management practices on competitiveness of grain milling firms in Usain Gishu County

The aggregate mean scores of total flow management practices(TFM) (independent variable) were regressed on the aggregate mean score of competitiveness (dependent variable) and the research findings for the effect of total flow management practices on competitiveness were outlined in table 9. The individual regression results reveal that total flow management practices explained $37.1 \%$ (Adjusted R2 = .371) variation on competitiveness of gain milling firms. This shows that $37.1 \%$ changes in competitiveness of grain milling firms could be accounted to changes in total flow management practices while other factors not considered in this study account for only $62.9 \%$ of the changes in competitiveness of grain milling firms. The $R$ value .611 shows that there is a positive significant correlation between total flow management practices and competitiveness at $\mathrm{p}<0.05$.

Table 9. Model Summary

\begin{tabular}{lllccc}
\hline & & \multicolumn{3}{c}{ Adjusted R } & Std. Error of the \\
Model & $\mathrm{R}$ & R Square & Square & Estimate & Durbin-Watson \\
\hline 1 & $.611^{\mathrm{a}}$ & .374 & .371 & .396 & 1.467 \\
\hline
\end{tabular}

a. Predictors: (Constant), TFM

b. Dependent Variable: Competitiveness 
The ANOVA results in table 10 revealed that there is significance of F statistics (117.647) is 0.000 which is less than 0.05 . This implies that there is a significant relationship between TFM and competitiveness as seen in table 10. This tested the null hypothesis and indicated that total TFM significantly affects competitiveness in grain milling firms in Uasin Gishu county. Thus, the rejection of the null hypothesis. These findings were supported by Chiocca, Guizzi, Murino, Revetria and Romano, (2012), Coleman Sr, (2014).

\section{Table 10. ANOVA ${ }^{a}$}

\begin{tabular}{llccll}
\hline & Sum of & & & & \\
Model & Squares & df & Mean Square & F & Sig. \\
\hline Regression & 18.477 & 1 & 18.477 & 117.647 & $.000^{\mathrm{b}}$ \\
Residual & 30.940 & 197 & .157 & & \\
Total & 49.417 & 198 & & & \\
\hline
\end{tabular}

a. Dependent Variable: Competitiveness

b. Predictors: (Constant), TFM

The regression coefficients table 11 showed the contribution of the independent variable to the dependent variable. Finally, from the data in Table 15, the study established regression equation was $\mathrm{Y}=2.753+.411 \mathrm{X} 1$. Therefore, competitiveness in grain milling firms in Uasin Gishu county $=2.753+.411$ TFM.

From the above regression equation it was revealed that holding TFM to a constant zero, competitiveness in grain milling firms in Uasin Gishu county would be be at 2.753 units. A unit increase in TFM would lead to increase in competitiveness in grain milling firms in Uasin Gishu county by a factor of 0.411 ( $\mathrm{B}=0.411$, $\mathrm{P}<0.05)$.

Table 11. Regression Coefficients ${ }^{a}$

\begin{tabular}{lcccccccr}
\hline & \multicolumn{2}{l}{$\begin{array}{l}\text { Unstandardized } \\
\text { Coefficients }\end{array}$} & \multicolumn{2}{c}{$\begin{array}{l}\text { Standardized } \\
\text { Coefficients }\end{array}$} & & & & \\
Model \\
Model & $\mathrm{B}$ & Std. Error & Beta & $\mathrm{T}$ & Sig. & Tolerance & VIF \\
\hline 1 (Constant) & 2.753 & .147 & & 18.682 & .000 & & \\
TFM & .411 & .038 & .611 & 10.847 & .000 & 1.000 & 1.000 \\
\hline
\end{tabular}

a. Dependent Variable: Competitiveness 
Journal of Business Management and Economic Research (JOBMER), Vol.5, Issue.3, pp.64-94

4.2.3. Effect of lean management practices on competitiveness of grain milling firms in Usain Gishu County

From the findings in table 12 the value of adjusted $\mathrm{R}$ squared is 0.459 an indication that there is a variation of $45.9 \%$ on the competitiveness in grain milling firms in Uasin Gishu county due to total production maintenance(TPM) and total flow management(TFM) at 95\% confidence interval. This shows that $45.9 \%$ changes in competitiveness in grain milling firms could be accounted to changes in total production maintenance and total flow management while other factors not considered in this study account for only $54.1 \%$ of competitiveness in grain milling firms. $\mathrm{R}$ is the correlation coefficient which shows the relationship between the study variables. From the findings shown in the table above there was a fairly strong positive relationship between lean management practices and competitiveness as shown by 0.682 .

Table 12. Model Summary

\begin{tabular}{llcccc}
\hline & & & & & \\
Model & $\mathrm{R}$ & R Square & Adjusted R Square & $\begin{array}{c}\text { Std. Error of the } \\
\text { Estimate }\end{array}$ & Durbin-Watson \\
\hline 1 & $.682^{\mathrm{a}}$ & .465 & .459 & .367 & 1.561 \\
\hline
\end{tabular}

a. Predictors: (Constant), TFM and TPM

b. Dependent Variable: Competitiveness

The statistical significance of this value was reported in the ANOVA table where the analysis results revealed that the significance of F statistics $(85.150)$ is 0.000 which is less than 0.05 . This implies that there is a significant relationship between lean management practices understudy and competitiveness as seen in table 13. This tested the null hypothesis and indicated that lean management practices significantly affects competitiveness in grain milling firms in Uasin Gishu county. Thus, the rejection of the null hypothesis. These findings were supported by (Bakar et al, 2017; Iranmanesh, Zailani, Hyun, Ali \& Kim, 2019; Anvari, Zulkifli, Yusuff, Hojjati \& Ismail, 2011) who also found that lean management practices signifficantly affects competitiveness of an organization. 
Journal of Business Management and Economic Research (JOBMER), Vol.5, Issue.3, pp.64-94

Table 13. ANOVAa

\begin{tabular}{llrrrrr}
\hline Model & & Sum of Squares & df & Mean Square & F & \multicolumn{1}{c}{ Sig. } \\
\hline 1 & Regression & 22.975 & 2 & 11.487 & 85.150 & $.000^{\mathrm{b}}$ \\
& Residual & 26.442 & 196 & .135 & & \\
& Total & 49.417 & 198 & & & \\
\hline
\end{tabular}

a. Dependent Variable: Competitiveness

b. Predictors: (Constant), TFM, and TPM

Based on the regression coefficients it was revealed that TFM and TPM to a constant zero competitiveness in grain milling firms in Uasin Gishu county would be at 1.971 table 14. A unit increase in TFM would lead to an increase in competitiveness in grain milling firms by a factor of $0.367(\mathrm{~B}=0.367, \mathrm{P}<0.05)$ and a unit increase in TPM would lead to increase in competitiveness in grain milling firms by a factor of 0.237 $(\mathrm{B}=0.237, \mathrm{P}<0.05)$. Therefore there is a significant relationships between all the independent variables (lean management practices) and the dependent variable (competitiveness in grain milling firms) since all the $\mathrm{P}$ values a less than 0.05 .

Therefore, the model adopted was:

$\mathrm{Y}=1.971+0.237 \mathrm{X} 1+0.367 \mathrm{X} 2$

Where $Y=$ competitiveness,

$\mathrm{X} 1=$ total production maintenance practices,

$\mathrm{X} 2=$ total flow management practices,

Table 14. Coefficients ${ }^{a}$

\begin{tabular}{lccccccc}
\hline & \multicolumn{2}{c}{$\begin{array}{c}\text { Unstandardized } \\
\text { Coefficients }\end{array}$} & $\begin{array}{c}\text { Standardized } \\
\text { Coefficients }\end{array}$ & & \multicolumn{3}{c}{ Collinearity Statistics } \\
Model & $\mathbf{B}$ & Std. Error & Beta & $\mathbf{t}$ & Sig. & Tolerance & VIF \\
\hline 1 (Constant) & 1.971 & .192 & & 10.252 & .000 & & \\
TPM & .237 & .041 & .309 & 5.774 & .000 & .955 & 1.047 \\
TFP & .367 & .036 & .546 & 10.210 & .000 & .955 & 1.047 \\
\hline
\end{tabular}

a. Dependent Variable: Competitiveness 
Journal of Business Management and Economic Research (JOBMER), Vol.5, Issue.3, pp.64-94

\subsection{Discussion of Results}

The study sought to investigate the effect of lean management practices on competitiveness of grain milling firms in Uasin Gishu County. The hypotheses tested were derived from the objectives of the study as discussed.

\subsubsection{Effect of total production maintenance practices on competitiveness of grain milling firms} in Uasin Gishu County

The first objective of the study was to establish the effect of total production maintenance practices on competitiveness of grain milling firms in Uasin Gishu County. The first hypothesis stated in the null form was as:

$\mathbf{H}_{01:}$ Total production maintenance practices have no statistically significant effect on competitiveness of grain milling firms in Uasin Gishu County.

TPM emphasizes proactive and preventative maintenance to maximize the operational efficiency of equipment. It blurs the distinction between the roles of production and maintenance by placing a strong emphasis on empowering operators to help maintain their equipment (Digalwar \& Nayagam, 2014). The findings of the study revealed that the value of adjusted $R$ squared is 0.176 an indication that there is a variation of $17.6 \%$ on competitiveness of grain milling firms due to total production maintenance practices at $95 \%$ confidence interval. The F statistics (43.342) was also significance a P less than 0.05 . This implies that there is a significant relationship between total production maintenance practices and competitiveness as seen in table 7.

There was also a fairly strong positive relationship between the study variables as shown by $R$ which is 0.425. All these together led to the rejection of the null hypothesis thus total production maintenance practices significantly affects competitiveness. These findings were supported by Habidin, Hashim, Fuzi and Salleh, (2018) and Jain, Bhatti and Singh (2014) who also found a positive and significant effect of total production maintainance and competitiveness. In addition, the findings are in line with both porters generic theory and resource based view. This implies that the management of the grain milling industry or companies should continuously implement and improve on the culture of getting operators maintaining their own equipment and laying emphasis on preventive and proactive maintenance which is crucial for improved production (fewer stoppages, breakdowns and defects). 
Journal of Business Management and Economic Research (JOBMER), Vol.5, Issue.3, pp.64-94

4.3.2. Effect of total flow management practices on competitiveness of grain milling firms in Uasin Gishu County

The second objective of the study was to find out the effect of total flow management practices on competitiveness of grain milling firms in Uasin Gishu County. The second hypothesis was stated in the null form was as:

Ho2: Total flow management practices have no statistically significant effect on competitiveness of grain milling firms in Uasin Gishu County.

From the findings total flow management practices explained 37.1\% (Adjusted $\mathrm{R} 2=.371$ ) variation on competitiveness of grain milling firms. This shows that $37.1 \%$ changes in competitiveness of grain milling firms could be accounted to changes in total flow management practices while other factors not considered in this study account for only $62.9 \%$ of the changes in competitiveness of grain milling firms. The $\mathrm{R}$ value .611 shows that there is a positive significant correlation between total flow management practices and competitiveness at $\mathrm{p}<0.05$. Besides there is significance of F statistics (117.647) with a P value less than 0.05. This implies that there is a significant relationship between TFM and competitiveness as seen in table 10. This tested the null hypothesis and indicated that total TFM significantly affects competitiveness in grain milling firms in Uasin Gishu county. Thus, the rejection of the null hypothesis. These findings were supported by Chiocca, Guizzi, Murino, Revetria and Romano, (2012), Coleman Sr, (2014) who also found a positive and significant effect of TFM and competitiveness. These findings are supported by both Porters generic theory and resource based view. This further implies that for the grain milling firms to remain competitive there is a need for them to strategically reorganise their work process and activities such as operation \& sales planning, logistics, purchases, production, quality and distribution which affects the entire chain of value.

4.3.3. Effect of lean management practices on competitiveness of grain milling firms in Uasin Gishu County

The general objective of the study was to investigate the effect of lean management practices on competitiveness of grain milling firms in Uasin Gishu County. The focus of lean management is to eliminate all the non-value adding parts of a process to the consumer. Besides it remains a key function in manufacturing for purposes of waste reduction which results from fluctuating demand from customers. These explains positive impact and core values of lean management practices on enhancing 
competitiveness and performance of organizations. This is further underpinned by the findings of this study which revealed that the value of adjusted $R$ squared is 0.465 an indication that there is a variation of $46.5 \%$ on the competitiveness in grain milling firms in Uasin Gishu county due to total production maintenance (TPM) and total flow management (TFM) at 95\% confidence interval.

This implies that there is a significant relationship between lean management practices understudy and competitiveness as seen in table 4.11. These findings were supported by (Bakar et al, 2017; Iranmanesh, Zailani, Hyun, Ali \& Kim, 2019; Anvari, Zulkifli, Yusuff, Hojjati \& Ismail, 2011) who also found that lean management practices signifficantly affects competitiveness of an organization. Based on the regression coefficients it was revealed that Thus, the companies should embrace all of the lean management practices. This implies that grain milling companies should emphasize on waste reduction across the business processes to engender competitiveness. All the lean management practices under study have a significant effect on competitiveness as supported by both Porters generic theory and resource based view.

\section{Conclusion}

The study concluded that the combined effect of lean management practices on competitiveness was significantly greater than the separate effect the lean management practices on competitiveness. Thus TFM and TPM had a synergistic effect on competitiveness of grain milling firms in Uasin Gishu County. This implies that the strategic bundling of these lean management practices remains a strategic pillar for competitiveness. However, TFP as an independent practice and even when joined with other practices caused the greatest effect on competitiveness while TPM had the least effect on competitiveness in both scenarios. In spite of these all the practices both independently and jointly had a significant effect on competitiveness thus non can be held in low esteem. It is therefore important to potentiate the extent of effect of lean management practices through continuous investment in their improvement and implementation for sustained competitiveness. Besides an increase in the total production maintainance has a positive increase in competitiveness. In addition, total flow management practices help organizations to minimize expenses in tune with consumer demands as adduced to the levers of competitiveness. Finally, the findings are supported by empirical literature and subscribes to the aspirations of both porters generic theory and resource based view.

Thus, the grain milling companies should continuously implement and improve on the culture of getting operators maintaining their own equipment and laying emphasis on preventive and proactive maintenance which is crucial for improved production (fewer stoppages, breakdowns and defects). Besides the grain 
Journal of Business Management and Economic Research (JOBMER), Vol.5, Issue.3, pp.64-94

milling firms should invest in training their employees on total production maintenance practices. In terms of total flow management practices there is need for adopting countermeasures to reduce waste and enhancing a better flow on information and materials. Grain milling firms need to strategically reorganize their work process and activities such as operation \& sales planning, logistics, purchases, production, quality and distribution which affects the entire chain of value. In fine the flow between interface of materials, information, employees, customers or support resources should be cost effective and efficient.

\section{References}

Abhishek, J., Harwinder, S., \& Rajbir, S. (2014). Total productive maintenance (TPM) implementation practice. Retrieved from www.researchgate.net

Agu, O. (2016). Effect of inventory management on the organizational performance of the selected manufacturing firms. Singaporean Journal of BuSineSS economicS, and management StudieS (SJBem), 5(4),56-70.

Amin, M. A., \& Karim, M. A. (2012). A systematic approach to evaluate the process improvement in lean manufacturing organizations. In Sustainable manufacturing (pp. 65-70). Berlin, Heidelberg. Springer.

Andae, G. (2019). Unga steps up competition with Eldoret wheat plant. Retrieved from www.businessdailyafrica.com

Anvari, A., Zulkifli, N., Yusuff, R. M., Hojjati, S. M., \& Ismail, Y. (2011). A proposed dynamic model for a lean roadmap. African Journal of Business Management, 5(16), 6727-6737.

Aziz, R. F., \& Hafez, S. M. (2013). Applying lean thinking in construction and performance improvement. Alexandria Engineering Journal, 52(4), 679-695.

Badli Shah, M. ( 2012.). "Total productive maintenance: a study of Malaysian automotive SMEs." . In Proceedings of the World Congress on Engineering, 3.

Bakar, N. A., Mat, T. Z., Fahmi, F. M., \& Urus, S. T. (2017). Lean management practices and its effect on Malaysian Local Government performance. Asia-Pacific Management Accounting Journal, 12(2), 79104.

Bakri, A. H., Rahim, A. R., Yusof, N. M., \& Ahmad, R. ( 2012). Boosting lean production via TPM. ProcediaSocial and Behavioral Sciences, 65, 485-491.

Chiocca, D., Guizzi, G., Murino, T., Revetria, R., \& Romano, E. (2012). A methodology for supporting lean healthcare. In Modern Advances in Intelligent systems and tools (pp. 93-99). Springer, Berlin, Heidelberg.

Clark, D. M., Silvester, K., \& Knowles, S. ( 2013). Lean management systems: creating a culture of continuous quality improvement. Journal of Clinical Pathology, 66(8), 638-643.

da Silva, A. T., Gohr, C. F., \& Santos, L. C. (2019). Lean production from the perspective of the resourcebased view: a study in an organization in the footwear industry. SciELO Analytics , 2(2),321-337.

Demeter, K., Losonci, D., Matyusz, Z., \& Jenei, I. (2009). The impact of lean management on business level performance and competitiveness. In Rapid Modelling for Increasing Competitiveness (pp. 177-198). London: Springer.

Digalwar, A. K., \& Nayagam, P. V. (2014). Implementation of total productive maintenance in manufacturing industries: a literature-based metadata analysis. IUP Journal of Operations Management, 13(1), 39-53. 
Ernest, O. N., King, B. D., Esther, A., Kwadwo, A. N., \& AY, A. R. (2019). The effect of lean operations in manufacturing on firm performance: the case of manufacturing firms in ACCRA. International Journal of Engineering Research and Reviews, 7( 2),1-7).

Ewert, P. K. (2016). Factors Determining Industrial Competitiveness And The Role Of Spillovers . The Journal of Applied Business Research, 32(2),527-540 .

Flinchbaugh, J. (1998). Implementing lean manufacturing through factory design. Doctoral dissertation, Massachusetts Institute of Technology.

Forrester, P. L., Shimizu, U. K., Soriano-Meier, H., Garza-Reyes, J. A., \& Basso, L. F. (2010). Lean production, market share and value creation in the agricultural machinery sector in Brazil. Journal of Manufacturing Technology Management, 21(7), 853-871.

Gomanga. (2019). Maize millers close shop, send workers home over grain shortage. Retrieved from tv47.co.ke

Govender, C. M., \& Jasson, C. C. (2018). Lean Practices for Efficiency in the South African Hospitality Sector. African Journal of Hospitality, Tourism and Leisure, 7(2), 1-14.

Haddad, T. H., \& Jaaron, A. A. (2012). The applicability of total productive maintenance for healthcare facilities: an implementation methodology. International Journal of Business, Humanities and Technology, 2(2), 148-155.

Hanged, W. S., \& Kumar, S. (2013). TPM-a key strategy for productivity improvement in medium scale industry. International Journal of Emerging Technology and Advanced Engineering, 3(6), 485-492.

Iranmanesh, M., Zailani, S., Hyun, S. S., Ali, M. H., \& Kim, K. (2019). Impact of Lean Manufacturing Practices on Firms' Sustainable Performance: Lean Culture as a Moderator. Sustainability, 11(4), 1112.

Jain, A., Bhatti, R., \& Singh, H. (2014). Total productive maintenance (TPM) implementation practice. International Journal of Lean Six Sigma,5 (3), 293-323.

Keitany, P., \& Riwo-Abudho, M. (2014). Effects of lean production on organizational performance. European journal of logistics purchasing and supply chain management, 2(2), 1-14.

Keny, F. S. (2015). Total productive maintenance and performance of the kenya seed industry . University of Nairobi .

Kezia, P., \& Kumar, K. S. (2017). BLN Krishna Sai Lean Manufacturing in Food and Beverage Industry. International Journal of Civil Engineering and Technology, 8(5),23-39.

Klassen, A. C., Creswell, J., Clark, V. L., Smith, K. C., \& Meissner, H. I. (2012). Best practices in mixed methods for quality of life research. Quality of Life Research, 21(3), 377-380.

Kozlenkova, I. V., Samaha, S. A., \& Palmatier, R. W. (2014). Resource-based theory in marketing. . Journal of the Academy of Marketing Science, 42(1), 1-21.

Kulkarni, A. B., \& Dabade, B. (2013). Technology (IJDMT). J Impact Fac, 4(1), 14-29.

Liang, T. P., You, J. J., \& Liu, C. C. (2010). A resource-based perspective on information technology and firm performance: a meta analysis. Industrial Management \& Data Systems, 110(8), 1138-1158.

Lin, Y., \& Wu, L. Y. (2014). Exploring the role of dynamic capabilities in firm performance under the resource-based view framework. Journal of business research, 67(3), 407-413.

Mohamed, A. F., \& Mwanyota, M. J. (2018). Effects of selected lean management practices on financial performance of private hospitals in Mombasa County, Kenya. International Journal of Supply Chain Management, 3(2), 1-21.

Molina. (2019). Total Flow Management in OnAutomation. Retrieved from www.onautomation.com

Mor, R., Singh, S., \& Bhardwaj, A. (2016). Learning on Lean Production: A Review of Opinion and Research within Environmental Constraints. Operations and Supply Chain Management, 9(1), 61 -72.

Myers, J. L., Well, A., \& Lorch, R. F. (2010). Research design and statistical analysis. . Routledge. 
Negrão, L. L., Godinho, F. M., \& Marodin, G. (2017). Lean practices and their effect on performance: a literature review. Production Planning \& Control, 28(1), 33-56.

Ngugi, K. (2015). Total productive maintenance practices and total productive maintenance practices and cement limited. University of Nairobi unpublished thesis.

Noble, H., \& Smith, J. ( 2015). Issues of validity and reliability in qualitative research. . Evidence-based nursing, 18(2), 34-35.

Panneerselvam, M. K. (2012). TPM implementation to invigorate manufacturing performance: an Indian industrial rubric. International Journal of Scientific \& Engineering Research, 3(6), 1-10.

Patty, M. (2016). Porter's Diamond Model. Retrieved from www.toolshero.com assesed on 9052020

Piercy, N., \& Rich, N. (2015). The relationship between lean operations and sustainable operations. International Journal of Operations \& Production Management, 35( 2), 282-315.

Porter, M. E. (2011). Competitive advantage of nations: creating and sustaining superior performance. simon and schuster.

Sadegh, R., Senin, A., \& Tourani, A. (2015). Effect of Organizational Factors on University-Industry Collaboration: A Conceptual Model. . International Journal of Business and Management, 10(6), 188215.

Sharma, K., Gera, G., Kumar, R., Chaudhary, H. K., \& Gupta, S. K. (2012). An empirical study approach on TPM implementation in manufacturing industry. International Journal on Emerging Technologies, 3(1), 18-23.

Shroeder, R., Goldstein, S., \& Rungtusanatham, M. (2011). Operations management: contemporary concepts and cases. 5th edition, New York: McGraw-Hill.

Sony, M. (2019). Lean Supply Chain Management and Sustainability: A Proposed Implementation Model. In Ethical and Sustainable Supply Chain Management in a Global Context (pp. 57-76). IGI Global.

Sparrow, P., Hird, M., \& Cooper, C. L. (2015). Lean management and organizational effectiveness. In Do We Need HR? (pp. 86-110). London: Palgrave Macmillan.

Tansey, P., Spillane, J. P., \& Meng, X. ( 2014). Linking response strategies adopted by construction firms during the 2007 economic recession to Porter's generic strategies. Construction management and economics, 32(7-8), 705-724.

Technoserve, U. (2008). The Dairy Value Chain in Uganda. East African dairy development.

Wachuma, P., \& Shalle, N. (2016). Effect of Lean Supply Chain Management Practices on Organizational Performance in Government Ministries in Kenya: A Case of Children's Department in the MLSSS. International Journal of Academic Research in Business and Social Sciences, 6(5), 364-375.

Wong, W., \& Wong, K. (2014). Synergizing an ecosphere of lean for sustainable operations . J.Clean. Prod, $85,51-66$.

WorldBank. (2014). Doing Business 2015: Going beyond Efficiency; Washington, DC. .

Zu, X., Robbins, T. L., \& Fredendall, L. D. (2010). Mapping the critical links between organizational culture and TQM/Six Sigma practices. International journal of production economics, 123(1), 86-106. 